\title{
Effects of tachykinin neuropeptide NKB and $A \beta$ (25-35) on antioxidant enzymes status in $17 \beta$ estradiol treated aging female rats
}

\author{
Rashmi Jha ${ }^{1,2}$, Abbas Ali Mahdi ${ }^{2}$, Shivani Pandey ${ }^{2}$, Najma Z. Baquer ${ }^{1}$, Sudha M. Cowsik ${ }^{1^{\star}}$ \\ ${ }^{1}$ School of Life Sciences, Jawaharlal Nehru University, New Delhi, India; ${ }^{*}$ Corresponding Author: scowsik@yahoo.com \\ ${ }^{2}$ King George's Medical University, Lucknow, India \\ Received 19 May 2013; revised 19 June 2013; accepted 26 June 2013 \\ Copyright (C) 2013 Rashmi Jha et al. This is an open access article distributed under the Creative Commons Attribution License, \\ which permits unrestricted use, distribution, and reproduction in any medium, provided the original work is properly cited.
}

\begin{abstract}
Aging is the leading risk factor for neurodegenerative diseases and oxidative stress involved in the pathophysiology of these diseases. These changes increase during menopausal condition in females when the level of estradiol is decreased. The aim of the present study was to determine the effect of tachykinin neuropeptide, Neurokinin B (NKB) and Amyloid beta fragment $A \beta(25-35)$ on $17 \beta$ estradiol (E2) treated aging female rat synaptosomes of different age groups. Aging brain functions were assayed by measuring the activities of antioxidant enzymes-superoxide dismutase (SOD) and monoamine oxidase (MAO) with neuropeptides. An in-vitro incubation of $A \beta(25$ - 35) in E2 treated brain synaptosomes showed toxic effects on all the parameters. However, NKB and NKB combined with $A \beta(25-35)$ showed stimulating effects in E2 treated rat brain synaptosomes. In the present study, an increase in activity of SOD and decrease in the level of MAO, in the presence of NKB and combined NKB and $A \beta$ in E2 treated brain synaptosomes of aging rats. This study elucidates that treatment of NKB and $A \beta$ with E2 in combination exerts more protective influence than their individual application, against excitotoxicity in age related changes.
\end{abstract}

Keywords: Aging; Neurokinin B; Amyloid Beta (25 - 35); Estradiol; Antioxidant Enzymes

\section{INTRODUCTION}

Aging is a time-dependent functional decline, leading to the cell's incapacity to withstand external and internal challenges. With aging, there is a physiological decline and an increase in the prevalence of diseases [1]. It is the consequence of two independent biological processes: the loss of functionality, and the loss of resistance or adaptability to stress. Increase in reactive oxygen species (ROS) production and imbalance in antioxidant defense and repair mechanism leads to cell death during aging and age related neurological disorders [2]. Highly ROS cause cell damage, including lipid peroxidation, inactivation of enzymes, alteration of intracellular oxidationreduction state and resultant damage in aging brain [3].

The ovarian steroid hormone E2 is one of the most important hormones, and it can protect neurons against A $\beta$ toxicity, oxidative stress and excitotoxicity [4-6]. The effect of E2 is primarily mediated by ERa and ERb which are members of the nuclear receptor superfamily of ligand-activated transcription factors [7]. E2 modulates multiple functions of the brain, via activation of $\mathrm{ERa}$ and ERb including development, cognition and memory [8], highlighting its protective effects against neuronal damage [9].

There are significant gender differences in the human brain diseases. For example, females on hormone replacement therapy (HRT) are significantly less likely to suffer from Alzheimer's disease (AD) than men [10]. There has been growing interest in the action and functions of the E2, particularly on whether they are neuronprotective for such age related diseases and neurodegenerative conditions like stroke, Alzheimer's disease (AD) and Parkinson's disease (PD) [11].

Peptides and proteins convert under some conditions from their native soluble state into highly ordered fibrillar aggregates. Such transitions are associated with numerous illnesses such as AD and PD [12]. The major constituents of amyloid plaques are fibrils formed from $\mathrm{A} \beta$. The aggregation pathway involves the formation of intermediate oligomers that elongate to form fibrils. 
These oligomers are believed to be the major neurotoxic species [13].

Mammalian tachykinins comprise a family of regulatory peptides including substance $\mathrm{P}$ (SP), neurokinin A (NKA) and neurokinin B (NKB) [14,15]. They are known to reduce oxidative stress in the brain [16-18]; to reverse the neurotoxic effects of $\mathrm{A} \beta$ in neurons and a role in neurodegenerative diseases $[19,20]$.

E2 treatment had beneficial effects on antioxidant enzymes in aging rat tissues as reported earlier by Baquer and colleagues [5]. In the present study, we examine the neuroprotective effect of $\mathrm{NKB}$ and with $\mathrm{E} 2$ against $\mathrm{A} \beta$ $(25-35)$ toxicity on the activity of superoxide dismutase and monoamine oxidase in the brain of aging female rats.

\section{MATERIALS AND METHODS}

\subsection{Animals}

The present study was conducted on female albino rats of the Wistar strain in different age groups (3, 12 and 24 months). Animals were maintained in the animal house facility of Jawaharlal Nehru University (JNU), New Delhi, India at a constant temperature of $25^{\circ} \mathrm{C}$, humidity $55 \%$ and $12 \mathrm{~h}$ dark and light cycle. The animals were fed standard chow rat feed (Hindustan Leaver Ltd., India) and given tap water until the time of sacrifice. The Institutional Animal Ethics Committee (IAEC) of JNU approved all the animal experiments; all institutional guidelines for care of animals were followed.

\subsection{Hormone Administration}

Subcutaneous injections of E2 $(0.1 \mu \mathrm{g} / \mathrm{g}$ body weight $)$ were given daily for one month, to the aged rats (12 and 24 months old; $\mathrm{n}=8$ for each group). E2 was dissolved in propylene glycol in appropriate concentrations [21]. Control animals received an equal volume of vehicle. There was no treatment on the day of the sacrifice. Animals of all the groups were sacrificed and brains were isolated for further study.

\subsection{Preparation of Synaptosomes}

The animals from control and E2 treated groups were sacrificed by cervical dislocation. The whole brain was excised and washed in ice-cold saline $(0.9 \% \mathrm{NaCl})$. Tissue homogenates were prepared as described by Mayanil et al. 1982 [22]. Tissues were soaked, dried on blotting paper and weighed, minced and homogenized in nine volumes of homogenizing buffer containing $0.25 \mathrm{M}$ sucrose, $0.02 \mathrm{M}$ triethanolamine $(\mathrm{pH} 7.4)$ and $0.12 \mathrm{mM}$ dithiothreitol. The pellet obtained after centrifugation at 12,000 (rpm) containing synaptosomes and mitochondria were taken for the present study. The whole procedure was carried out at $4^{\circ} \mathrm{C}$.

\subsection{Treatment of Synaptosomes with NKB and $A \beta(25-35)$}

Each sample containing $\sim 100 \mu \mathrm{g}$ protein of isolated rat brain synaptosome was incubated with $\mathrm{NKB}, \mathrm{A} \beta(25-35)$ and $\mathrm{NKB}+\mathrm{A} \beta(25-35)$ in microfuge tubes at $37^{\circ} \mathrm{C}$ for $60 \mathrm{~min}$ in a shaking water bath with $0.1,1$ and $5 \mu \mathrm{M}$ concentration of each of the peptides. All incubations were performed in four combinations; control (without any peptide), $\mathrm{A} \beta(25-35), \mathrm{NKB}$ and $\mathrm{NKB}+\mathrm{A} \beta(25-35)$ in three age groups of control and $\mathrm{E} 2$ treated rats at three peptide concentrations.

\subsection{Measurement of Superoxide Dismutase (SOD) Activity}

Synaptosomes prepared from rat brains of different age groups were treated with Triton X-100, and Mn-SOD activity was determined by the pyrogallol autoxidation. Pyrogallol is known to autoxidize rapidly in alkaline solution and the reaction has been employed for the removal of oxygen from gases [23]. The SOD activity was measured in the synaptosomes isolated from 3, 12 and 24-month-old control rat (without E2 treatment), and E2 treated rat brain synaptosomes in the presence and absence of $\mathrm{A} \beta(25-35), \mathrm{NKB}$ and combined NKB and $\mathrm{A} \beta$ $(25-35)$. The activity of SOD activity expressed as units per mg protein per minute. One unit of the enzyme activity defined as the amount of enzyme that causes halfmaximal inhibition of pyrogallol autoxidation.

\subsection{Measurement of Monoamine Oxidase (MAO) Activity}

The MAO activity was measured in the synaptosomes isolated from 3, 12 and 24-month-old control rats (without E2 treatment), and E2 treated rat brain synaptosomes in the presence and absence of $\mathrm{A} \beta(25-35), \mathrm{NKB}$ and combined $\mathrm{NKB}$ and $\mathrm{A} \beta(25$ - 35). MAO activity was assayed according to the method of Catravas et al. 1977 [24] with minor modifications. The amount of the reaction product i.e. 4-hydroxyquinoline formed was determined spectrophotometrically at $330 \mathrm{~nm}$. One unit of the enzyme defined as $1 \mu \mathrm{mol}$ of 4-hydroxyquinoline pro$\mathrm{duced} / \mathrm{mg}$ protein $/ \mathrm{min}$ at $37^{\circ} \mathrm{C}$.

\subsection{Protein Estimation}

Protein was estimated in the synaptosomes by the method of Bradford, 1976 [25] using bovine serum albumin (BSA) as standard.

\subsection{Statistical Analysis}

Data have been presented as mean \pm standard error of mean (SEM). The data were analyzed using one way ANOVA to test for differences between different treat- 
ments at different age groups. Differences between the means of the individual groups were assessed by Dunnett's multiple comparisons test. A value of $p<0.05$ was considered to be statistically significant.

\subsection{Chemicals}

All substrates, standards, NKB and A $\beta$ (25 - 35) peptide fragment were purchased from Sigma Chemicals Company, USA. All other chemicals were of analytical grade and purchased from SRL and Qualigens, India.

\section{RESULTS}

\subsection{Effect of E2 on General Physiological Parameters in Aging}

The changes in general parameters like body weight, brain weight and protein concentration in brain synaptosomes from different rat age groups namely 3, 12 and 24 months, are presented in Table 1. In this study, we observed an increase in body weight and brain weight in 12 and 24-month-old control rats when compared to 3-month young rats (Result stated in the Table 1) but weight decreased significantly with E2 treatment when compared with respective controls. However, protein content increased significantly in rat brain synaptosomes of E2 treated rats. It was observed that protein content increased by $49 \%$ ( $p<0.001)$ in 12 -month-old control rat brain synaptosomes and $66 \%(\mathrm{p}<0.05)$ in E2 treated 12-month-old rat brain synaptosomes. Protein content was calculated as mg per gm of whole brain.

\subsection{Superoxide Dismutase (SOD)}

Changes in SOD activity were measured in rat brain synaptosomes, in different age groups with and without $\mathrm{E} 2$ treatment, at different concentration $\mathrm{A} \beta$ (25 - 35), $\mathrm{NKB}$ and $\mathrm{NKB}+\mathrm{A} \beta(25-35)$. The Results are shown in Figures 1(a)-(c).

\subsubsection{Effect of E2 and Varying Concentrations of $A \beta(25$ - 35) on SOD Activity}

The SOD activity was found to be reduced in the synaptosomes of control (without E2) rat brain incubated with different concentrations of $\mathrm{A} \beta(25$ - 35). However, decrease in the activity was less in E2 treated rat synaptosomes. Incubation of $5 \mu \mathrm{M}$ of $\mathrm{A} \beta(25-35)$ in E2 treated 12 and 24-month-old rat brain synaptosomes showed less decrease as compared to incubation of $0.1 \mu \mathrm{M}$ and $1 \mu \mathrm{M}$ of $\mathrm{A} \beta(25-35)$ in 12 and 24-month control rats $(\mathrm{p}<0.05$ and $\mathrm{p}<0.05)$. The results are shown in Figure 1(a).

\subsubsection{Effect of E2 and Varying Concentrations of NKB on SOD Activity}

The activity of SOD was observed to increase in all control age groups with NKB incubation, whereas this increase in enzyme activity was more significant in E2 treated rats, as compared to age matched control groups. Increase in SOD activity was highly significant in E2 treated group of 12 and 24-month-old rat using a dose of $5 \mu \mathrm{M}$ of NKB namely $57 \%$ and $72 \%(\mathrm{p}<0.01$ and $\mathrm{p}<$ 0.01 ) respectively. The results are shown in Figure 2(b).

\subsubsection{Effect of E2 and Varying Concentrations of Combined NKB and A $\beta(25$ - 35) on SOD Activity}

The SOD activity in control synaptosomes was observed to increase when treated with a combination of $\mathrm{NKB}$ and $\mathrm{A} \beta(25-35)$, but this increase was more significant in synaptosomes of E2 treated 12 and 24-month aging rats. The combined dose of NKB and $\mathrm{A} \beta(25-35)$ at $5 \mu \mathrm{M}$ concentration in 24-month E2 treated rats showed a significantly raised SOD activity as compared to matched control $(\mathrm{p}<0.01)$. The results are shown in Figure 1(c).

\subsection{Monoamine Oxidase (MAO)}

Changes in MAO activity were measured in rat brain

Table 1. Body weight, Brain tissue weight and synaptosomal protein of 3,12 and 24-month control (C) and estradiol (E2) treated female rats.

\begin{tabular}{ccccc}
\hline Age/Treatment & Body Weight & Brain Weight & $\begin{array}{c}\text { Brain Weight/100gm } \\
\text { Body Weight }\end{array}$ & Protein (mg/gm) \\
\hline 3-month (C) & $202 \pm 14.37$ & $1.65 \pm 0.05$ & $0.81 \pm 0.11$ & $10.48 \pm 0.55$ \\
12-month (C) & $323 \pm 19.46^{\S}$ & $2.05 \pm 0.07^{\sharp}$ & $0.63 \pm 0.09$ & $15.65 \pm 0.35^{\S}$ \\
12-month (E2) & $267 \pm 10.44^{\mathrm{c}}$ & $1.86 \pm 0.10$ & $0.57 \pm 0.07$ & $17.48 \pm 0.61^{\mathrm{c}}$ \\
24-month (C) & $380 \pm 13.32^{\S}$ & $1.94 \pm 0.13$ & $0.51 \pm 0.10$ & $13.54 \pm 0.72^{\#}$ \\
24-month (E2) & $321 \pm 13.82^{\mathrm{c}}$ & $1.80 \pm 0.13$ & $0.56 \pm 0.12^{\mathrm{a}}$ & $16.64 \pm 0.70^{\mathrm{b}}$ \\
\hline
\end{tabular}

Each value is a mean \pm SEM of five or more separate values from two or three experiments. The comparison of experimental values is with the control values. Stastical significane: ${ }^{\mathrm{a}} \mathrm{p}<0.001,{ }_{\mathrm{p}}^{\mathrm{b}}<0.01,{ }^{\mathrm{c}} \mathrm{p}<0.05$ comparising age matched control verses E2 treatment, ${ }^{\$} \mathrm{p}<0.001,{ }^{\#} \mathrm{p}<0.01$ verses 3 months. 


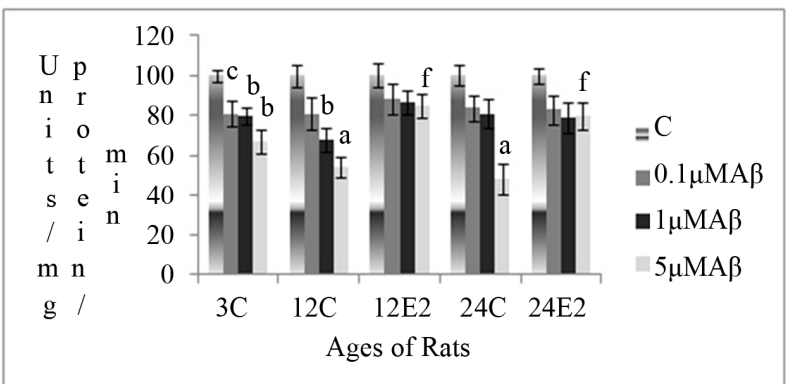

(a)

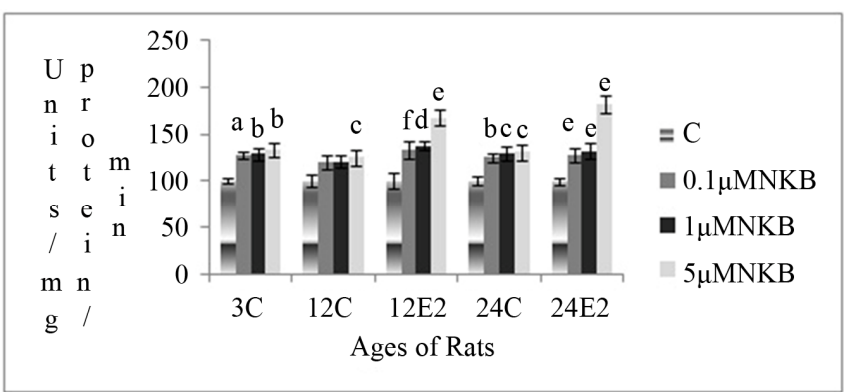

(b)

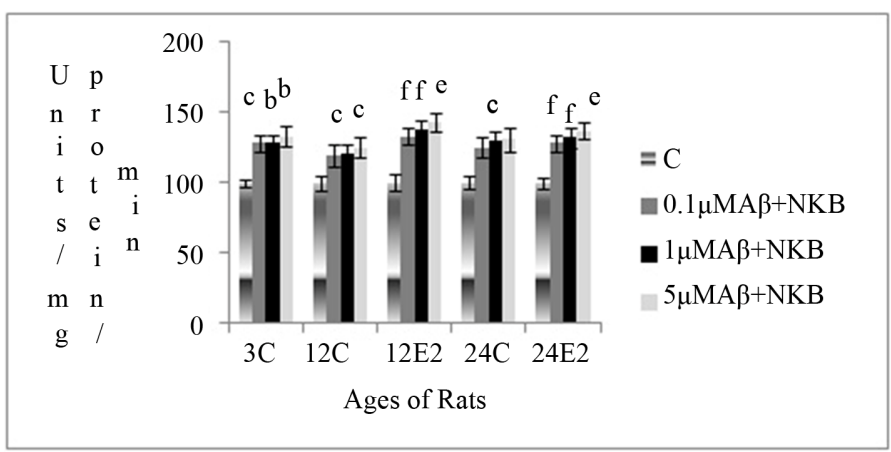

(c)

Figure 1. Percentage changes in the SOD activity in synaptosomes of 3,12 and 24-month control (C) and estradiol (E2) treated aging female rats in presence of (a) $\mathrm{A} \beta(25-35)$ (b) $\mathrm{NKB}$ and (c) $\mathrm{NKB}+\mathrm{A} \beta(25-35)$. Peptide concentrations are $0.1,1.0$ and $5.0 \mu \mathrm{M}$. Statistical significance: ${ }^{\mathrm{a}} \mathrm{p}<0.001,{ }^{\mathrm{b}} \mathrm{p}<0.01,{ }^{\mathrm{c}} \mathrm{p}<0.05$ comparing age matched control (untreated) versus peptide treated; ${ }^{\mathrm{d}} \mathrm{p}<0.001$, ${ }_{\mathrm{e}}^{\mathrm{e}}<0.01,{ }_{\mathrm{p}}^{\mathrm{f}}<0.05$ comparing E2 treated versus peptide treated.

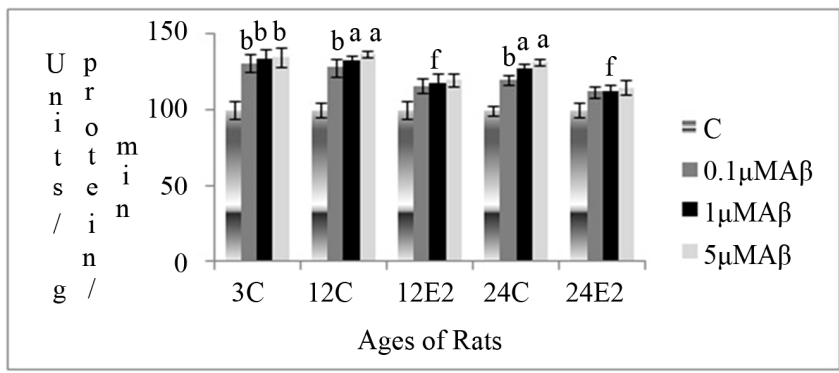

(a)

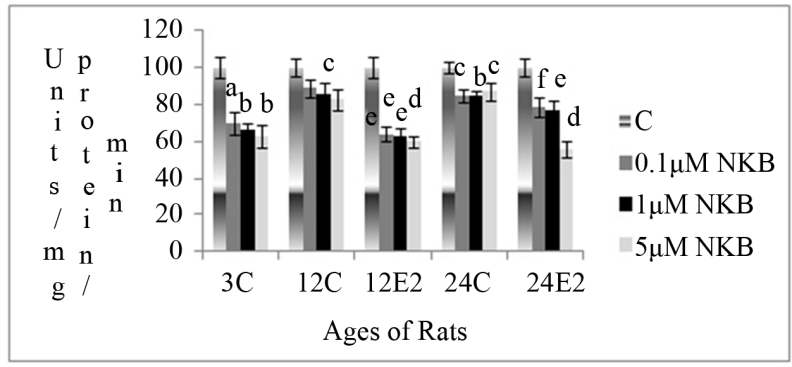

(b)

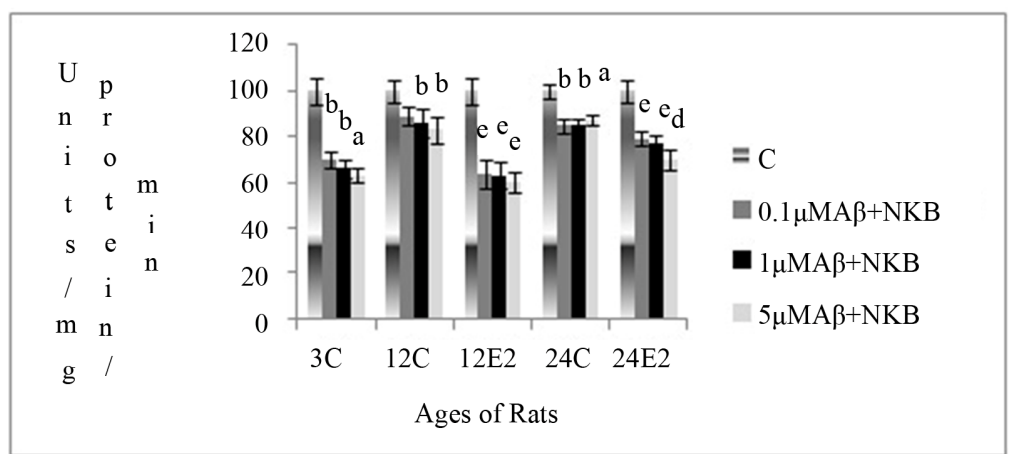

(c)

Figure 2. Percentage changes in the MAO activity in synaptosomes of 3,12 and 24-month control (C) and estradiol (E2) treated aging female rats in presence of (a) $\mathrm{A} \beta(25$ - 35) (b) NKB and (c) NKB $+\mathrm{A} \beta(25$ - 35). Peptide concentrations are $0.1,1.0$ and 5.0 $\mu \mathrm{M}$. Statistical significance: ${ }^{\mathrm{a}} \mathrm{p}<0.001,{ }^{\mathrm{b}} \mathrm{p}<0.01,{ }^{\mathrm{c}} \mathrm{p}<0.05$ comparing age matched control (untreated) versus peptide treated; ${ }^{\mathrm{d}} \mathrm{p}<$ $0.001,{ }^{\mathrm{e}} \mathrm{p}<0.01,{ }_{\mathrm{f}}^{\mathrm{p}}<0.05$ comparing E2 treated versus peptide treated. 
synaptosomes, in different age groups with and without E2 treatment, at different concentration $\mathrm{A} \beta(25-35)$, $\mathrm{NKB}$ and $\mathrm{NKB}+\mathrm{A} \beta(25-35)$. Results are shown in Figures 2(a)-(c).

\subsubsection{Effect of E2 and Varying Concentrations of $A \beta(25-35)$ on MAO Activity}

The MAO activity was found to be increased in the synaptosomes of control rats (E2 untreated), when incubated with different concentrations of $\mathrm{A} \beta$ (25 - 35). However, this increase in the activity was less in E2 treated rat brain synaptosomes. In the synaptosomes of E2 treated 24-month rats, the enzyme activity was increased with incubation of $\mathrm{A} \beta(25$ - 35) at $1 \mu \mathrm{M}$ concentration $(\mathrm{p}<0.05)$. Results are shown in Figure 2(a).

\subsubsection{Effect of E2 and Varying Concentrations of NKB on MAO Activity}

The MAO activity decreased in the synaptosomes of control rats of different age groups with different concentrations of NKB. However, there was less marked decrease in enzyme activity, in E2 treated aging rats with different concentrations of NKB incubation. The activity of MAO decreased by $64 \%$ in $24-$ month E2 treated rats, when incubated with $5 \mu \mathrm{M}$ concentration of NKB ( $\mathrm{p}<$ 0.001). Results are shown in Figure 2(b).

\subsubsection{Effect of E2 and Varying Concentrations of Combined NKB and A $\beta(25-35)$ on SOD Activity}

The SOD activity in control synaptosomes was observed to increase when treated with a combination of $\mathrm{NKB}$ and $\mathrm{A} \beta(25-35)$, but this increase was more significant in synaptosomes of E2 treated 12 and 24-month aging rats. The combined dose of $\mathrm{NKB}$ and $\mathrm{A} \beta(25-35)$ at $5 \mu \mathrm{M}$ concentration in 24-month E2 treated rats showed a significantly raised SOD activity as compared to matched control $(\mathrm{p}<0.01)$. The results are shown in Figure 1(c).

\subsection{Monoamine Oxidase (MAO)}

Changes in MAO activity were measured in rat brain synaptosomes, in different age groups with and without $\mathrm{E} 2$ treatment, at different concentration $\mathrm{A} \beta$ (25 - 35), $\mathrm{NKB}$ and $\mathrm{NKB}+\mathrm{A} \beta(25-35)$. Results are shown in Figures 2(a)-(c).

\subsubsection{Effect of E2 and Varying Concentrations of $A \beta(25-35)$ on MAO Activity}

The MAO activity was found to be increased in the synaptosomes of control rats (E2 untreated), when incubated with different concentrations of $\mathrm{A} \beta$ (25 - 35). However, this increase in the activity was less in E2 treated rat brain synaptosomes. In the synaptosomes of E2 treated 24-month rats, the enzyme activity was increased with incubation of $\mathrm{A} \beta(25-35)$ at $1 \mu \mathrm{M}$ concentration $(\mathrm{p}<0.05)$. Results are shown in Figure 2(a).

\subsubsection{Effect of E2 and Varying Concentrations of NKB on MAO Activity}

The MAO activity decreased in the synaptosomes of control rats of different age groups with different concentrations of NKB. However, there was less marked decrease in enzyme activity, in E2 treated aging rats with different concentrations of NKB incubation. The activity of MAO decreased by $64 \%$ in 24 -month E2 treated rats, when incubated with $5 \mu \mathrm{M}$ concentration of $\mathrm{NKB}(\mathrm{p}<$ 0.001). Results are shown in Figure 2(b).

\subsubsection{Effect of E2 and Varying Concentrations of Combined NKB and A $\beta(25$ - 35) on MAO Activity}

The MAO activity was found to be decreased in the synaptosomes isolated from E2 treated rats, when incubated with combined NKB and $\mathrm{A} \beta(25-35)$. The synaptosomes isolated from E2 treated 24-month rats showed a decrease in the MAO enzyme activity with an incubation of $5 \mu \mathrm{M}$ of the combined NKB and $\mathrm{A} \beta(25-35)$ as compared to age matched control $(\mathrm{p}<0.001)$. Results are shown in Figure 2(c).

\section{DISCUSSION}

In this study, we observed the increased body weight and brain weight in controls (E2 untreated), but these parameters decreased significantly in E2 treated rats. The above finding could be due to the deposition of adipose tissue during normal aging; however this accumulation reduced due to anti-obesity action of E2 in treated groups. The protein concentrations in E2 treated rats slightly increased when compared with age matched controls. This observation is supported by the earlier findings of Kumar et al. 2011 [5]. Earlier data from a previous study showed decreased levels of E2 at 12 and 24 months as compared to the 3-month rats [26].

Further the activity of SOD was assessed in the presence of different concentrations of $\mathrm{A} \beta(25-35)$, NKB and combined treatment of NKB and $\mathrm{A} \beta(25-35)$ in various age groups of untreated and E2 treated rat brain synaptosomes. It was observed that the activity of SOD increased in brain synaptosomes of all the age groups with an incubation of $\mathrm{NKB}$ and combined $\mathrm{NKB}$ and $\mathrm{A} \beta$, as compared with that of age matched control synaptosomes. This observation is also supported by the results of Mantha et al. 2006 [17]. In the current study, at different concentrations of $\mathrm{A} \beta(25$ - 35) treatment, a decrease in SOD activity was observed in the synaptosomes of control rats (E2 untreated) of different age 
groups The reduced activity of SOD with $\mathrm{A} \beta(25-35)$ treatment may be due to increased oxidative stress produced by the amyloids in the brain. These findings are supported by an earlier study in the literature [27]. In the present study, the treatment of $\mathrm{A} \beta(25-35)$ in E2 treated and untreated synaptosomes showed a decrease in SOD activity although the percentage decrease in the activity was comparatively less in E2 treated group. This result shows that E2 plays a neuromodulatory and neuroprotective role against oxidative stress produced by $\mathrm{A} \beta$ (25 $35)$. However, the SOD activity at different concentrations of NKB in E2 treated rat brain synaptosomes showed more significant increase as compared to their individual application. As per this result, E2 showed increased protective action in the presence of NKB. This increased protection may be due to the antioxidant property of the NKB whereby it reduces the free radical production as well as increased SOD synthesis in the synaptosomes. The combination therapy of NKB and $\mathrm{A} \beta(25-$ $35)$ again on E2 treated and untreated group showed a rise in enzyme activity, although SOD activity increased significantly in E2 treated group. These results show that NKB along with E2 reversed the action of $\mathrm{A} \beta(25-35)$, which is neurotoxic and causes degeneration by free radical generation.

We have studied the MAO activity in different concentrations of $\mathrm{A} \beta(25-35)$, NKB and combined treatment of NKB and $\mathrm{A} \beta(25-35)$ in various age groups of untreated and E2 treated rats brain synaptosomes. The MAO activity in brain synaptosomes, incubated with $\mathrm{A} \beta$ (25 - 35), resulted in an elevation of its activity in a dose dependent manner. This observation has been supported by Song et al. 2000 [28]. When we studied the MAO activity in E2 treated rats synaptosomes incubated with A $\beta$ (25 - 35), insignificant increase was observed compared to that of untreated E2 rats. These observations indicate that $\mathrm{A} \beta(25-35)$ showed less toxicity in the presence of E2 as compared to without E2 treated rats synaptosomes. It was observed that MAO activity in E2 treated synaptosomes, with an increase in the concentrations of NKB showed a sharp decrease as compared with that of the age matched untreated controls. Combined application of NKB and $\mathrm{A} \beta(25$ - 35) reversed the amyloid induced increase in MAO activity, in rats of different age groups. Present results obtained with E2 and NKB suggest their role as an antioxidant and free radical scavenger agent against $\mathrm{A} \beta(25-35)$ induced deleterious effects in synaptosomes. By reducing the oxidative stress, observed in aging and by amyloid toxicity in the brain, NKB with E2 may contribute to the control of the aging process.

\section{CONCLUSION}

This study demonstrated that the combination treat- ment of NKB and E2 have significantly positive effects as compared to their individual application, and exerts its antagonism and protective influence against excitotoxicity and aging related changes. This suggests that interaction between peptides and estradiol may exist. Therefore, it can be concluded that neuroprotection by estrogen with neurokinin B holds immense promise for applying new strategies for control of age related neurodegenerative diseases.

\section{ACKNOWLEDGEMENTS}

Financial grant from University Grant Commission, New Delhi, India in the form of project is gratefully acknowledged.

\section{REFERENCES}

[1] Abrass, I.B. (1990) The biology and physiology of aging. Western Journal of Medicine, 153, 641-645.

[2] Bodis, W.I., Chang, E., Ghilardi, M.F., Glover, A., Onfrj, M., Pasik, P. and Samson, Y. (1991) Acetyl-Levocarnitine protect against MPTP-induced Parkinsonism in primates. Journal of Neural Transmission-Parkinson's Disease and Dementia Section, 3, 63-72. http://dx.doi.org/10.1007/BF02251137

[3] Baquer, N.Z., Taha, A., Kumar, P., McLean, P., Cowsik, S.M., Kale, R.K., Singh, R. and Sharma, D. (2009) A metabolic and functional overview of brain aging linked to neurological disorders. Biogerontology, 10, 377-413. http://dx.doi.org/10.1007/s10522-009-9226-2

[4] Brann, D.W., Krishnan, D., Chandramohan, W., Virendra, B.M. and Mohammad, M.K. (2007) Neurotrophic neuroprotective actions of estrogen: Basic mechanism and clinical implications. Steroids, 72, 381-405. http://dx.doi.org/10.1016/j.steroids.2007.02.003

[5] Kumar, P., Taha, A., Kale, R.K., Cowsik, S.M. and Baquer, N.Z. (2011) Physiological and biochemical effects of $17 \beta$ estradiol in aging female rat brain. Experimental Gerontology, 46, 597-605. http://dx.doi.org/10.1016/j.exger.2011.02.008

[6] Moorthy, K., Yadav, S.U.C., Mantha, A.K., Cowsik, S.M., Sharma, D. and Baquer, N.Z. (2004) Effect of estradiol and progesterone treatment on lipid profile in naturally menopausal rats from different age groups. Biogerontology, 5, 1-9. http://dx.doi.org/10.1007/s10522-004-3190-7

[7] Gronemeyer, H., Gustafsson, J.A. and Laudet, V. (2004) Principles for modulation of the nuclear receptor superfamily. Nature Reviews Drug Discovery, 3, 950-964. http://dx.doi.org/10.1038/nrd1551

[8] Spencer, J.L., Waters, E.M., Romeo, R.D., Wood, G.E., Millner, T.A. and McEwen, B.S. (2008) Uncovering the mechanism of estrogen effects on hippocampal function. Frontiers in Neuroendocrinology, 29, 219-237. http://dx.doi.org/10.1016/j.yfrne.2007.08.006

[9] Garcia-Segura, L.M., Azcoitia, I. and DonCarlos, L.L. (2001) Neuroprotection by estradiol. Progress in Neurobiology, 63, 29-60.

http://dx.doi.org/10.1016/S0301-0082(00)00025-3 
[10] Compton, J., Van Amelsvoort, T. and Declan, M. (2003) HRT and its effect on normal aging of the brain and dementia. Journal of Clinical Pharmacology, 52, 647-653. http://onlinelibrary.wiley.com/doi/10.1046/j.0306-5251.2 001.01492.x/pdf

[11] Henderson, V.W. (2010) Action of estrogens in the aging brain: dementia and cognitive aging. Biochimica et Biophysica Acta, 1800, 1077-1083. http://dx.doi.org/10.1016/j.bbagen.2009.11.005

[12] Dobson, C.M. (2003) Protein folding and misfolding. Nature, 426, 884-890. http://dx.doi.org/10.1038/nature02261

[13] Hung, L.W., Ciccotosto, G.D., Giannakis, E., Tew, D.J., Perez, K., Masters, C.L., Cappai, R., Wade, J.D. and Barnham, K.J. (2008) Amyloid-beta peptide (Abeta) neurotoxicity is modulated by the rate of peptide aggregation: Abeta dimers and trimers correlate with neurotoxicity. The Journal of Neuroscience, 28, 11950-11958. http://dx.doi.org/10.1523/JNEUROSCI.3916-08.2008

[14] Patacchini, R., Lecci, A., Holzer, P. and Maggi, C.A. (2004) Newly discovered tachykinins raise new questions about their peripheral roles and the tachykinin nomenclature. Trends in Pharmacological Sciences, 25, 1-3. http://dx.doi.org/10.1016/j.tips.2003.11.005

[15] Almeida, T.A., Rojo, J., Nieto, P.M., Pinto, F.M., Hernandez, M., Martin, J.D. and Candenas, M.L. (2004) Tachykinins and tachykinin receptors: Structure and activity relationships. Current Medicinal Chemistry, 11, 20452081. http://dx.doi.org/10.2174/0929867043364748

[16] Turska, E., Lachowicz, L. and Wasiak, T. (1985) Effect of analogues of substance P fragments on the MAO activity in rat brain. General Pharmacology, 16, 293-295. http://dx.doi.org/10.1016/0306-3623(85)90088-6

[17] Mantha, A.K., Moorthy, K., Cowsik, S.M. and Baquer, N.Z. (2006) Neuroprotective role of neurokinin B (NKB) on amyloid $\beta(25-35)$ induced toxicity in aging rat brain synaptosomes: Involvement in oxidative stress and excitotoxicity. Biogerentology, 7, 1-17. http://dx.doi.org/10.1007/s10522-005-6043-0

[18] Mantha, A.K., Moorthy, K., Cowsik, S.M. and Baquer, N.Z. (2006) Membrane associated functions of neurokinin $\mathrm{B}(\mathrm{NKB})$ on $\mathrm{A} \beta(25-35)$ induced toxicity in aging rat brain synaptosomes. Biogerentology, 7, 19-33. http://dx.doi.org/10.1007/s10522-005-6044-z

[19] Yankner, B.A., Duffy, L.K. and Kirschner, D.A. (1990) Neurotrophic and neurotoxic effects of amyloid protein: Reversal by tachykinin neuropeptides. Science, 250, 279-
282. http://dx.doi.org/10.1126/science.2218531

[20] Kowall, N.W., Beal, M.F., Buscigliot, J., Duffyt, L.K. and Yankner, N.W. (1991) An in vivo model for the neurodegenerative effects of $\beta$ amyloid and protection by substance P. Neurobiology, 88, 7247-7251.

[21] Moorthy, K., Yadav, U.C.S., Siddiqui, M.R., Basir, S.F., Sharma, D. and Baquer, N.Z. (2004) Effect of estradiol and progesterone treatment on carbohydrate metabolizing enzymes in tissues of aging female rats. Biogerontology, 5, 249-259. http://dx.doi.org/10.1023/B:BGEN.0000038026.89337.02

[22] Mayanil, C.S., Kazmi, S.M. and Baquer, N.Z. (1982) $\mathrm{Na}^{+}$, $\mathrm{K}^{+}$-ATPase and $\mathrm{Mg}^{2+}$-ATPase activities in different regions of rat brain during alloxan diabetes. Journal of Neurochemistry, 39, 903-908. http://dx.doi.org/10.1111/j.1471-4159.1982.tb11475.x

[23] Marklund, S. and Marklund, G. (1974) Involvement of the super anion radicals in the autoxidation of pyrogollol and a convenient assay for superoxide dismutase. European Journal of Biochemistry, 47, 469-474. http://dx.doi.org/10.1111/j.1432-1033.1974.tb03714.x

[24] Catravas, G.N., Takenaga, J. and McHale, C.G. (1977) Effect of chronic administration of morphine on monoamine oxidase activity in discrete regions of the brain of rats. Biochemical Pharmacology, 26, 211-214. http://dx.doi.org/10.1016/0006-2952(77)90305-7

[25] Bradford, M.M. (1976) A rapid and sensitive method for the quantitation of microgram quantities of protein utilizing the principle of protein-dye binding. Analytical Biochemistry, 72, 248-254. http://dx.doi.org/10.1016/0003-2697(76)90527-3

[26] Moorthy, K., Sharma, D., Basir, S.F. and Baquer, N.Z. (2005) Administration of estradiol and progesterone modulate the activities of antioxidant enzyme and aminotransferases in naturally menopausal rats. Experimental Gerontology, 40, 295-302. http://dx.doi.org/10.1016/j.exger.2005.01.004

[27] Varadarajan, S., Kanski, J., Aksenova, M., Lauderback, C. and Butterfield, D.A. (2001) Different mechanisms of oxidative stress and neurotoxicity for Alzheimer's A beta $(1-42)$ and A beta $(25$ - 35). Journal of the American Chemical Society, 123, 5625-5631. http://dx.doi.org/10.1021/ja010452r

[28] Song, W., Zhou, L.J., Zheng, S.X. and Zhu, X.Z. (2000) Amyloid-beta 25-35 peptide induces expression of monoamine oxidase B in cultured rat astrocytes. Acta Pharmacologica Sinica, 21, 557-563. 